\title{
Biogeochemical transformations and potential polyaromatic hydrocarbon degradation in macrofaunal burrow sediments
}

\author{
W. K. Chung, Gary M. King* \\ Darling Marine Center, University of Maine, Walpole, Maine 04573, USA
}

\begin{abstract}
A variety of polyaromatic hydrocarbons (PA.H) including naphthalene, phenanthrene, acenaphthene, and dibenzothiophene were degraded with little or no lag in oxic slurries of marine sediments from burrow walls constructed by benthic macrofauna. PAH degradation potentials of burrow sediments from the polychaetes Nereis virens and Clymenella torquata, the mollusc Mya arenaria and the enteropneust Saccoglossus bromophenolosus were generally greater than potentials for non-burrow sediments; relative rates of degradation varied among the burrow wall sediments depending on the PAH assayed. Comparisons of the effects of available electron acceptors (oxygen, nitrate, ferric iron, sulfate) indicated that significant degradation of benzene, hexadecane and PAH occurred only in the presence of molecular oxygen. However, the capacity for oxic phenanthrene degradation was stable during incubations with alternating oxic and anoxic conditions, suggesting significant anoxia tolerance. Although burrow wall sediments were biogeochemically distinct with respect to rates of sulfate reduction, potential denitrification and potential ammonia oxidation, these patterns were not related to those of PAH degradation.
\end{abstract}

KEY WORDS: Polycyclic aromatic hydrocarbon $\cdot \mathrm{PAH} \cdot$ Benthic $\cdot$ Biodegradation $\cdot$ Macrofauna

\section{INTRODUCTION}

Polycyclic aromatic hydrocarbons (PAH) account for a significant fraction of crude oil and petroleum-based products (e.g. creosote; Sharak-Genther et al. 1997). In addition, $\mathrm{PAH}$ are derived from numerous natural sources, perhaps the most important of which is biomass burning (Jenkins et al. 1996). As a consequence of extensive fossil fuel use and pollution, PAH occur ubiquitously in marine systems, especially coastal systems that are subject to numerous intense point sources and less intense but widespread diffuse sources. Since many PAH are mutagenic or carcinogenic (Menzie et al. 1992), their fate has been the focus of extensive geochemical, biochemical, physiological and ecological analyses

\footnotetext{
- Addressee for correspondence

E-mail: gking@maine.edu
}

Results from early microbiological analyses suggested that PAH degradation depends on molecular oxygen to initiate ring cleavage (e.g. Delaune et al. 1981, Bauer \& Capone 1985, 1988, Mihelic \& Luthy 1988). However, some monoaromatics, e.g. benzene and toluene, are labile under anaerobic conditions (e.g. Grbic-Galic \& Vogel 1987, Lovley et al. 1989, Evans et al. 1991, Edwards et al. 1992). In addition, naphthalene and phenanthrene have been degraded under sulfate-reducing conditions in chronically contaminated sediment (Coates et al. 1997). Nevertheless, numerous recent studies indicate that aerobic transformations result in more extensive and rapid degrada. tion of a greater diversity of $\mathrm{PAH}$, including those with high molecular weights (Delaune et al. 1981, Boldrin et al. 1993, Fritzsche et al. 1994, Kanaly et al. 1997).

In coastal marine sediments, high rates of benthic oxygen uptake limit molecular oxygen to the upper several mm of sediment (e.g. Blackburn \& Blackburn 1993, Fenchel et al. 1998), thereby substantially con- 
straining the potential for aerobic PAH degradation Nonetheless, macrofaunal burrow ventilation with oxygenated water may facilitate sub-surface aerobic degradation, and in some cases inhibit anaerobic metabolism (Banta et al. 1999). The importance of burrows and burrow ventilation is evident from burrow surface area and ventilation rates. Kristensen (1984) has estimated that Nereis virens burrows at a modest density $\left(700 \mathrm{~m}^{-2}\right)$ increase the sediment-water interface area by $150 \%$; individual burrow ventilation rates up to $400 \mathrm{ml} \mathrm{h} \mathrm{h}^{-1}$ have been reported (Scott 1975). Ventilation with oxygenated surface water undoubtedly accounts for well-documented increases in aerobic ammonia oxidation rates in the burrows of diverse macrofauna (e.g. Sayama \& Kurihara 1983, Kristensen et al. 1985, 1991, Kristensen 1988, Pelegrí \& Blackburn 1996), and may contribute to enhanced transformations of iron, manganese, sulfur, and organic matter.

Anaerobic transformations are also enhanced in at least some burrows. This is due in part to the fact that ventilation and oxic conditions occur only intermittently (e.g. Scott 1975, Aller 1982, Kristensen 1988, Bussman \& Reichardt 1991). In the case of denitrification, enhanced activity is due to increased nitrate availability from nitrification during oxic periods and close coupling between these processes (Blackburn et al. 1994). Patterns of sulfate reduction vary more than those of nitrification and denitrification, with enhanced activity near burrows in some instances and apparent inhibition in others (Hansen et al. 1996, Giray \& King 1997). In this case, parameters other than ventilation and oxygen, e.g. organic matter supply, may be important. Regardless, burrows may be sites of enhanced anaerobic aromatic degradation by sulfate-reducing bacteria (Edwards et al. 1992, Rabus et al. 1993, Beller et al. 1996, Bedessem et al. 1997, Coates et al. 1997) or denitrifiers (Bossert \& Young 1986, Archangeli \& Arvin 1995).

In the present study, we examine PAH degradation potentials for burrow sediments from the polychaetes Clymenella torquata and Nereis virens, the mollusc Mya arenaria and the enteropneust Saccoglossus bromophenolosus. Radiotracers were used to compare degradation for benzene and hexadecane under oxic and anoxic conditions; stable substrates were used to assay oxic PAH degradation and to determine responses to periodic changes in oxygen availability. A suite of biogeochemical transformations, including sulfate reduction and denitrification, and an aerobic process, ammonia oxidation, were also measured to determine the extent to which different burrow and ventilation characteristics affect processes that may contribute to hydrocarbon biodegradation.

\section{MATERIALS AND METHODS}

Sediment collection. Burrow and non-burrow sediments were collected from the intertidal zone of Lowes Cove, Maine. This site has been described previously (e.g. Andersen et al. 1981, King et al. 1983, Rice 1986, Hansen et al. 1996); it is not significantly contaminated. Clymenella torquata burrows (semi-rigid tubes penetrating about 8 to $10 \mathrm{~cm}$ into the sediment surface) were collected intact since they consist of sediment cemented into a stable structure. $C$. torquata tubes were later homogenized for use in assays other than sulfate reduction. Mya arenaria burrow sediments were collected from upper Lowes Cove after exposing the animals with a clam fork. $M$. arenaria was typically found at a depth of 15 to $20 \mathrm{~cm}$; burrows were formed by extension of the animal's siphons to the sediment surface. Only the innermost ( 1 to $2 \mathrm{~mm}$ thick) oxidized, light brown layer of sediment from 5 to $10 \mathrm{~cm}$ depth surrounding the siphons was scrapped off with a spatula. Burrow sediments of Saccoglossus bromophenolosus and Nereis virens were collected similarly. In all cases, burrow identification was based on the animal occupants and burrow morphologies.

Sulfate reduction. Sulfate reduction was measured by direct injection of carrier-free ${ }^{35} \mathrm{SO}_{4}{ }^{2-}$ (approximately $37 \mathrm{kBq}[1 \mu \mathrm{Ci}] \mathrm{cm}^{-3}$ ) into $3 \mathrm{~cm}^{3}$ disposable syringes modified by removing the luer tips. For burrows of Mya arenaria, Nereis virens, and Saccoglossus bromophenolosus, sediments (inner $1 \mathrm{~mm}$ ) were collected using a spatula and then loaded into the syringes. For Clymenella torquata, bulk sediments were removed from intact burrow tubes; the tubes, with walls about $1 \mathrm{~mm}$ thick, were subsequently loaded into syringes. Modified $3 \mathrm{~cm}^{3}$ syringes were also used to obtain cores perpendicular to the burrow walls of $N$. virens, $M$. arenaria, and $C$. torquata. These cores were collected by carefully inserting syringe barrels into the sediment while holding the plunger steady at the inner surface of the burrow wall. Subsequent to incubation with a radiotracer, the cores were extruded and sectioned at $2 \mathrm{~mm}$ intervals or greater. Vertical profiles of non-burrow sediments were obtained using acrylic cores $(7.5 \mathrm{~cm}$ inner diameter) carefully positioned between obvious burrow openings at the sediment surface. These cores were subsampled at $1 \mathrm{~cm}$ intervals over a depth of $15 \mathrm{~cm}$. Details of radiotracer injection, sediment processing by chromous chloride distillation for radiosulfide formation after 3.5 to $4 \mathrm{~h}$ incubation and estimation of porewater sulfate concentrations follow Hansen et al. (1996) and Giray \& King (1997). All radioassays were conducted with a Wallac LKB model 1217 scintillation counter using internal standardization. 
Potential denitrification rate. Slurries of burrow sediments collected as above were prepared by mixing $10 \mathrm{~cm}^{3}$ of sediment with $20 \mathrm{~cm}^{3}$ of seawater in $160 \mathrm{~cm}^{3}$ serum bottles. The bottle headspaces were flushed with nitrogen and then the bottles were sealed with butyl stoppers. An additional set of slurries was prepared similarly using non-burrow sediment collected at $1 \mathrm{~cm}$ intervals over the 0 to $15 \mathrm{~cm}$ depth interval from intact cores. All slurries were incubated with shaking (190 rpm) at room temperature (about $20^{\circ} \mathrm{C}$ ) in the presence of an initial nitrous oxide concentration of $5000 \mathrm{ppm}$. Uptake rates of nitrous oxide were measured by sampling bottle headspaces $\left(1 \mathrm{~cm}^{3}\right)$ with a syringe and needle. Nitrous oxide concentrations were estimated by gas chromatography using a Varian model 3700 operated with a Porpak $Q$ column $(0.3 \mathrm{~cm}$ outer diameter $\times 1 \mathrm{~m}$ ) at $70^{\circ} \mathrm{C}$ with a helium carrier gas at $30 \mathrm{~cm}^{3} \mathrm{~min}^{-1}$ and detection by thermal conductivity. Potential denitrification rates were calculated from linear regression analysis during periods of maximum nitrous oxide depletion.

Potential ammonia oxidation rate. Aerobic slurries were prepared using burrow wall or surface sediments (upper 2 to $3 \mathrm{~mm}$ at the sediment-water interface) collected as above and diluted 1:10 with seawater in $160 \mathrm{~cm}^{3}$ serum bottles containing air. Ten $\mathrm{cm}^{3}$ of slurry in each bottle were incubated with vigorous shaking (190 rpm) at room temperature after adding ammonium chloride and sodium chlorate to final concentrations of 1 and $10 \mathrm{mM}$, respectively. Chlorate specifically inhibits nitrite oxidation; thus, nitrite accumulation serves as an index of ammonium oxidation (Belser \& Mays 1980). Nitrite accumulation was measured at intervals (Giray \& King 1997) after subsampling $200 \mu$ of slurry. Sediment was removed from slurry samples by microcentrifugation (11500 $\times$ g; $10 \mathrm{~min})$. Sample absorbances for the nitrite assay were measured using a Beckman model DU-610.

${ }^{14} \mathrm{C}$-hexadecane and ${ }^{14} \mathrm{C}$-benzene degradation. $\mathrm{n}$-[1${ }^{14} \mathrm{Clhexadecane}\left(2.15 \mathrm{GBq} \mathrm{mmol}^{-1}\right)$ was obtained from Amersham Life Science. [UL- ${ }^{14} \mathrm{C}$ ] benzene $(2.15 \mathrm{GBq}$ mmol $^{-1}$ ) was obtained from the Sigma Chemical Company. For aerobic degradation experiments, slurries were prepared under oxic conditions using a 1:10 dilution of burrow (Clymenella torquata and Mya arenaria) or non-burrow sediments in artificial seawater (ASW) (after Sverdrup et al. 1942). Ten $\mathrm{cm}^{3}$ of slurry were transferred to each of 2 sets of $160 \mathrm{~cm}^{3}$ polyethylene serum bottles containing a headspace of air. Approximately $37 \mathrm{kBq}{ }^{14} \mathrm{C}$-hexadecane (final slurry concentration, $2.4 \mathrm{nmol} \mathrm{cm}^{-3}$ ) or ${ }^{14} \mathrm{C}$-benzene (final slurry

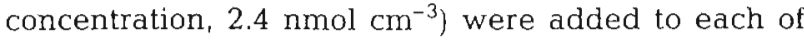
the replicate bottles in each set. All bottles were sealed with rubber stoppers fitted with a center well containing $0.2 \mathrm{ml}$ of $0.5 \mathrm{~N} \mathrm{KOH}$ to trap evolved ${ }^{14} \mathrm{CO}_{2}$. The bot- tles were incubated with shaking $(\sim 150 \mathrm{rpm})$ at room temperature in the dark. Center wells were removed from triplicates in each set at intervals; the well contents were added to scintillation vials containing $10 \mathrm{ml}$ of Scintiverse (Fisher Scientific, Inc.). Radioactivity was measured as noted above.

For anaerobic degradation assays, slurries were prepared under anoxic conditions in a glovebag containing nitrogen. Five $\mathrm{cm}^{3}$ of anoxic slurry were incubated in modified $5 \mathrm{~cm}^{3}$ syringes (luer tips removed) using ASW without sulfate. Radiotracers were added as above to sealed syringes but at $4.8 \mathrm{nmol} \mathrm{cm}^{-3}$. Nitrate, sulfate or ferric iron at final concentrations of $20 \mu \mathrm{mol}$ $\mathrm{cm}^{-3}$ were added to the slurries, except for the unamended controls. Ferric iron was used as a freshly precipitated oxyhydroxide. The syringes were incubated at room temperature in the dark in a reciprocating shaker ( $100 \mathrm{rpm})$ under an atmosphere of nitrogen. ${ }^{14} \mathrm{CO}_{2}$ production was measured at intervals by expressing subsamples into scintillation vials that were subsequently sealed with rubber stoppers fitted with center wells containing $0.2 \mathrm{ml}$ of $0.5 \mathrm{~N} \mathrm{KOH}$. The subsamples were acidified by injecting $2 \mathrm{ml}$ of $1 \mathrm{~N} \mathrm{HCl}$. Radioactivity from ${ }^{14} \mathrm{CO}_{2}$ trapped in $\mathrm{KOH}$ was measured as outlined above.

Aerobic PAH degradation. Stock solutions $(0.11 \mathrm{mM})$ of naphthalene, 1, 4-dimethylnaphthalene (1,4-DMN), acenaphthene, dibenzothiophene (DBT) and benz[a]anthracene were prepared individually in dichloromethane (DCM). These PAH are representative of commonly observed pollutants in coastal sediments. Individual stocks $(9 \mu \mathrm{l})$ were transferred into $40 \mathrm{~cm}^{3}$ glass serum bottles, each containing a small amount $(0.1 \mathrm{~g})$ of autoclaved bulk sediment as a carrier. The stock solution was mixed thoroughly into the sediment, and DCM evaporated for several minutes prior to the addition of $10 \mathrm{~cm}^{3}$ of burrow (Clymenella torquata and Mya arenaria) or non-burrow sediment slurries prepared as described above. The final PAH concentrations in the slurries were approximately $100 \mathrm{nmol} \mathrm{cm}^{-3}$. The bottles were sealed with Teflon-lined stoppers and aluminum-crimp seals, and incubated at room temperature with shaking $(\sim 150 \mathrm{rpm})$ in the dark. The bottles were flushed with air at regular intervals ( 2 to $3 \mathrm{~d}$ ). At intervals, triplicate bottles were sacrificed, and PAH extracted from the slurries.

Phenanthrene degradation under varied oxygen regimes. Sediment slurries (10\%) were prepared using Nereis virens burrow wall sediments and ASW. Ten $\mathrm{cm}^{3}$ volumes were transferred to $40 \mathrm{~cm}^{3}$ glass serum bottles subsequently sealed with. Teflon-lined stoppers. About $50 \mu \mathrm{g}$ of phenanthrene in $9 \mu \mathrm{l}$ of DCM were added to each bottle. The serum bottles were flushed with either air or nitrogen and incubated in darkness at ambient temperature with shaking 
$(150 \mathrm{rpm})$. The bottle headspaces were flushed daily with air or nitrogen to maintain oxic or anoxic conditions in 2 sets of replicates; in a third set, oxic and anoxic conditions were alternated on a daily basis. Triplicate bottles from each set were sacrificed at intervals, the contents were acidified, and phenanthrene was extracted with hexane for analysis as described below. In an additional experiment, slurries were prepared anaerobically as above, except that ASW without sulfate was used as a sediment diluent. Three sets were amended with nitrate, manganic oxide or ferric oxyhydroxide (both freshly produced) to final concentrations of $20 \mu \mathrm{mol} \mathrm{cm}{ }^{-3}$ slurry. The fourth set of bottles was not amended and was used as a control. These slurries were incubated under anoxic conditions as above prior to flushing the headspaces with air for oxic incubations. A set of autoclaved sediments was used as controls for abiological losses.

PAH extraction and quantification. Six $\mathrm{ml}$ of DCM:methanol (1:2) containing 1, 8-dimethylnaphthalene as an internal standard were added to $10 \mathrm{~cm}^{3}$ of slurry in serum bottles. The bottle contents were shaken for $2 \mathrm{~min}$; aqueous and organic phases were separated by centrifugation after transfer to $20 \mathrm{ml}$ glass screw-cap test tubes sealed with Teflon-lined caps. $\mathrm{PAH}$ in the organic phase were analyzed using a Varian model 3400 gas chromatograph (GC) equipped with a flame ionization detector and a SPB5 capillary column $(15 \mathrm{~m} \times 0.53 \mathrm{~mm}$ i.d., $1.5 \mu \mathrm{m}$ film thickness; Supelco). Peak areas from each sample were normalized for the internal standard; PAH concentrations were estimated from standard curves. Extraction efficiencies were $>95 \%$. Some samples were analyzed by gas chromatography-mass spectrometry (GC-MS) using a Hewlett Packard 6890 GC equipped with an HP5972A mass selective detector and an HP-5MS column ( $30 \mathrm{~m} \times 0.25 \mathrm{~mm}$ i.d.; $0.25 \mu \mathrm{m}$ film thickness).

\section{RESULTS}

\section{Sediment associated microbial processes}

Sulfate reduction rates (Table 1) were highest for pooled burrow wall sediments obtained from Nereis virens $\left(0.5 \pm 0.1 \mu \mathrm{mol} \mathrm{cm}{ }^{-3} \mathrm{~d}^{-1}\right)$, followed by rates for

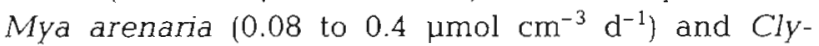
menella torquata $\left(0.1 \pm 0.01 \mu \mathrm{mol} \mathrm{cm} \mathrm{cm}^{-3} \mathrm{~d}^{-1}\right)$. Data from radial profiles around burrows showed a similar trend, with the highest rates for the inner $2 \mathrm{~mm}$ measured for
$N$. virens burrows $\left(0.5 \pm 0.1 \mu \mathrm{mol} \mathrm{cm}{ }^{-3} \mathrm{~d}^{-1}\right)$. Rates for the inner $2 \mathrm{~mm}$ of $C$. torquata and $M$. arenaria burrows were considerably lower $\left(0.1\right.$ to $\left.0.15 \mu \mathrm{mol} \mathrm{cm} \mathrm{cm}^{-3} \mathrm{~d}^{-1}\right)$. For all burrow transects, sulfate reduction increased gradually and significantly $(\mathrm{p}<0.05)$ with distance from the burrow wall, in the cases of $N$. virens and

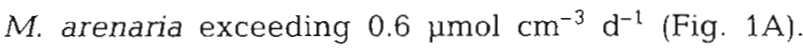
Rates for $C$. torquata and $M$. arenaria inner wall
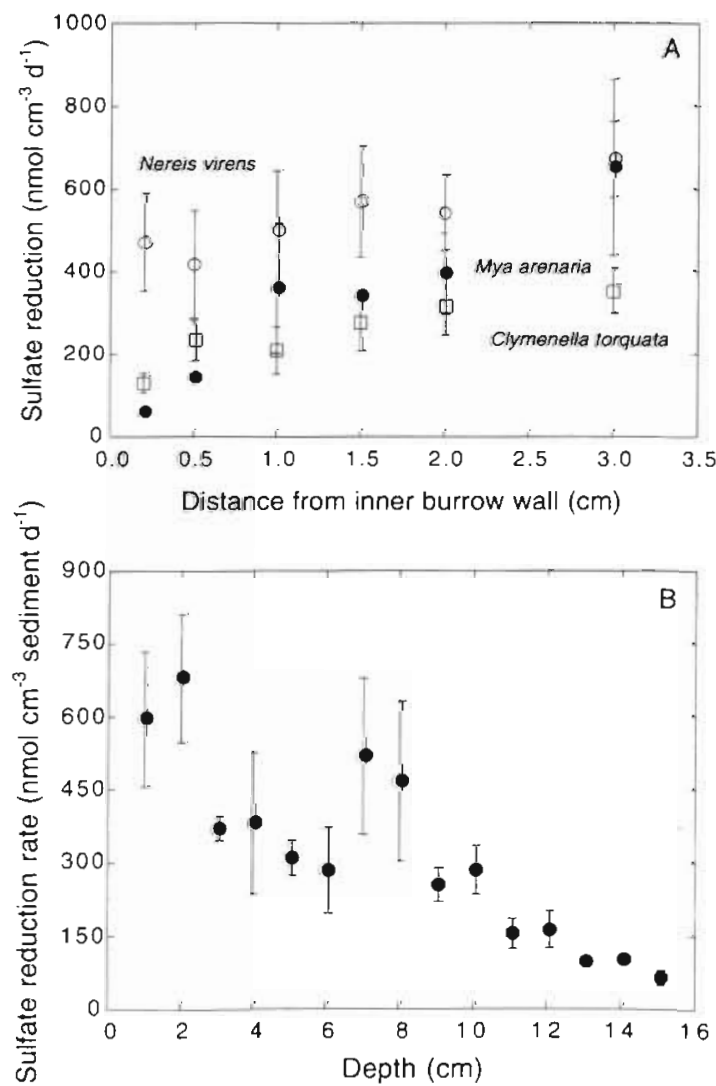

Fig. 1. (A) Radial profiles of sulfate reduction rates around burrows of Nereis virens (0), Mya arenaria (•), and Clymenella torquata ( ). (B) Depth profile of sulfate reduction in nonburrow sediments. All data are means of triplicates $\pm 1 \mathrm{SE}$ 
burrow sediments were generally lower than rates observed for non-burrow sediments over the upper $10 \mathrm{~cm}$ of a depth profile (Fig. 1B). However, within a distance of 1 to $2 \mathrm{~cm}$ from the burrow walls, rates for all burrow sediments were similar to those for non-burrow sediments. Sulfate reduction rates for non-burrow sediments decreased markedly with depth, from surface values of 0.59 to $0.68 \mu \mathrm{mol} \mathrm{cm} \mathrm{cm}^{-3} \mathrm{~d}^{-1}$ to values $<0.1 \mu \mathrm{mol} \mathrm{cm} \mathrm{c}^{-3} \mathrm{~d}^{-1}$ at depths $>12 \mathrm{~cm}$. A secondary subsurface maximum occurred at a depth of 6 to $8 \mathrm{~cm}$.

Maximum potential denitrification rates (PDNR, expressed as rates of nitrous oxide uptake) were highest in pooled Clymenella torquata burrow sediment slurries $\left(11.5 \pm 2.8 \mu \mathrm{mol} \mathrm{cm}^{-3} \mathrm{~d}^{-1}\right)$, followed by rates for Mya arenaria, Saccoglossus bromophenolosus and Nereis virens $(6.5 \pm 0.9,1.2 \pm 0.1$, and $1.1 \pm 0.1 \mu \mathrm{mol}$ $\mathrm{N}_{2} \mathrm{O}$ reduced $\mathrm{cm}^{-3}$ sediment $\mathrm{d}^{-1}$, respectively; Table 1 ). The maximum rates for all sediments were expressed after an initial lag of approximately $50 \mathrm{~h}$, during which nitrous oxide depletion was negligible (Fig. 2); subsequently, depletion was linear until headspace concentrations dropped to $<100 \mathrm{ppm}$. In general, rates for $C$. torquata and $M$. arenaria sediments substantially exceeded those for non-burrow sediments over the 0 to $15 \mathrm{~cm}$ depth interval. Rates for non-burrow sediments were highest at the surface $(0$ to $1 \mathrm{~cm})$, relatively uniform over the 1 to $10 \mathrm{~cm}$ interval, and then decreased from 10 to $15 \mathrm{~cm}$ depth (Fig. 3A,B).

In contrast to patterns for denitrification, maximum potential ammonia oxidation rates were greatest for Nereis virens burrow sediments $\left(1.4 \pm 0.2 \mu \mathrm{mol} \mathrm{cm}^{-3}\right.$ $\mathrm{d}^{-1}$; Table 1). Rates were significantly lower for Clymenella torquata and Saccoglossus bromophenolosus burrow sediments ( 36 to $57 \%$ ), and markedly lower $(79 \%)$ for those for Mya arenaria. All burrow sediment

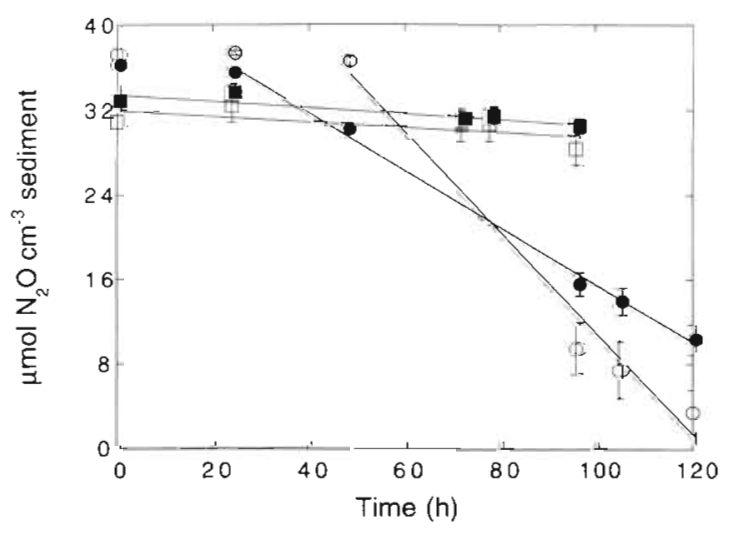

Fig. 2. Time course for nitrous oxide uptake in slurries of burrow wall sediment from Clymenella torquata (O), Mya arenaria ( ). Saccoglossus bromophenolosus (ם) and Nereis virens ( $\square$ ). All data are means of triplicates $\pm 1 \mathrm{SE}$. Regression lines for C. torquata and $M$. arenaria determined for data after a lag in uptake
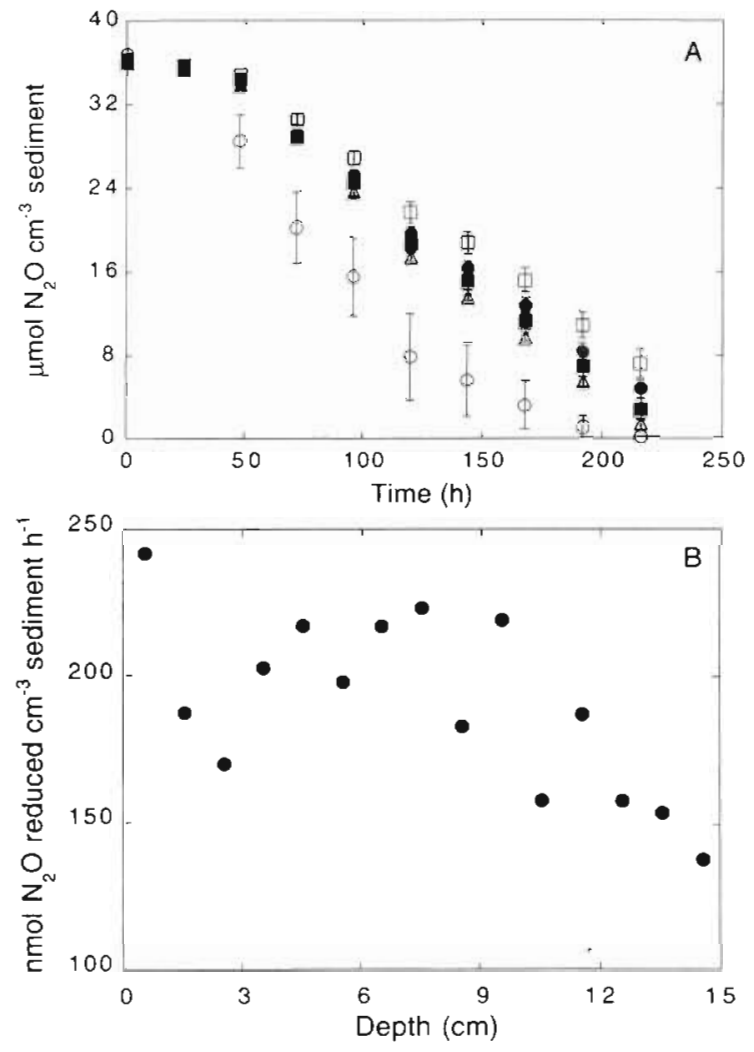

Fig. 3. (A) Representative time course for nitrous oxide in slurries of non-burrow sediments from 0 to $1 \mathrm{~cm} \mathrm{(0),} 1$ to $2 \mathrm{~cm}$

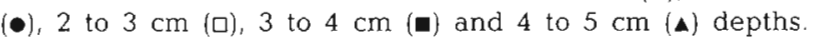
(B) Depth profile of maximum potential denitrification rates (nitrous oxide reduction) for non-burrow sediments. All data are means of triplicates $\pm 1 \mathrm{SE}_{i}$ for the depth profile, error bars are $<$ symbol size

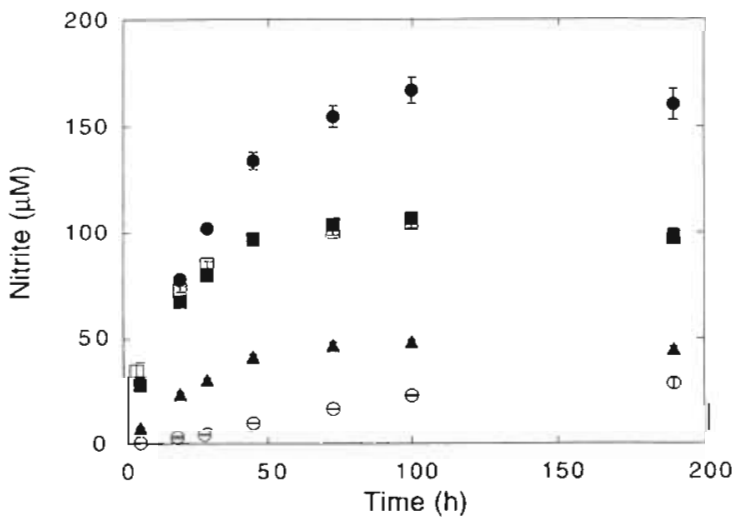

Fig. 4. Time courses for nitrite production by slurries of surface sediments $(0$ to $1 \mathrm{~cm}$ interval, 0$)$ and burrow wall sediments from Nereis virens (•), Saccoglossus bromophe-

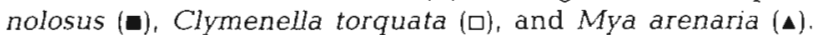
All data are means of triplicates $\pm 1 \mathrm{SE}$. Error bars not shown are $<$ symbol size 
rates were considerably greater (3.5- to 11 -fold) than rates for surface sediments. In all assays, nitrite concentrations reached a maximum after approximately 30 to $60 \mathrm{~h}$ incubation and remained constant thereafter (Fig. 4). However, the total amount of nitrite accumulated represented only a small fraction of the ammonium added $(<10 \%)$.

\section{${ }^{14} \mathrm{C}$-hexane and ${ }^{14} \mathrm{C}$-benzene degradation}

Over $53 \mathrm{~d},{ }^{14} \mathrm{CO}_{2}$ accumulated in a pattern consistent with exponentially decreasing degradation for added ${ }^{14} \mathrm{C}$-hexadecane and ${ }^{14} \mathrm{C}$-benzene (Fig. 5). Total ${ }^{14} \mathrm{CO}_{2}$ accumulated from ${ }^{14} \mathrm{C}$-hexadecane was consistently greater for oxic Mya arenaria than Clymenella
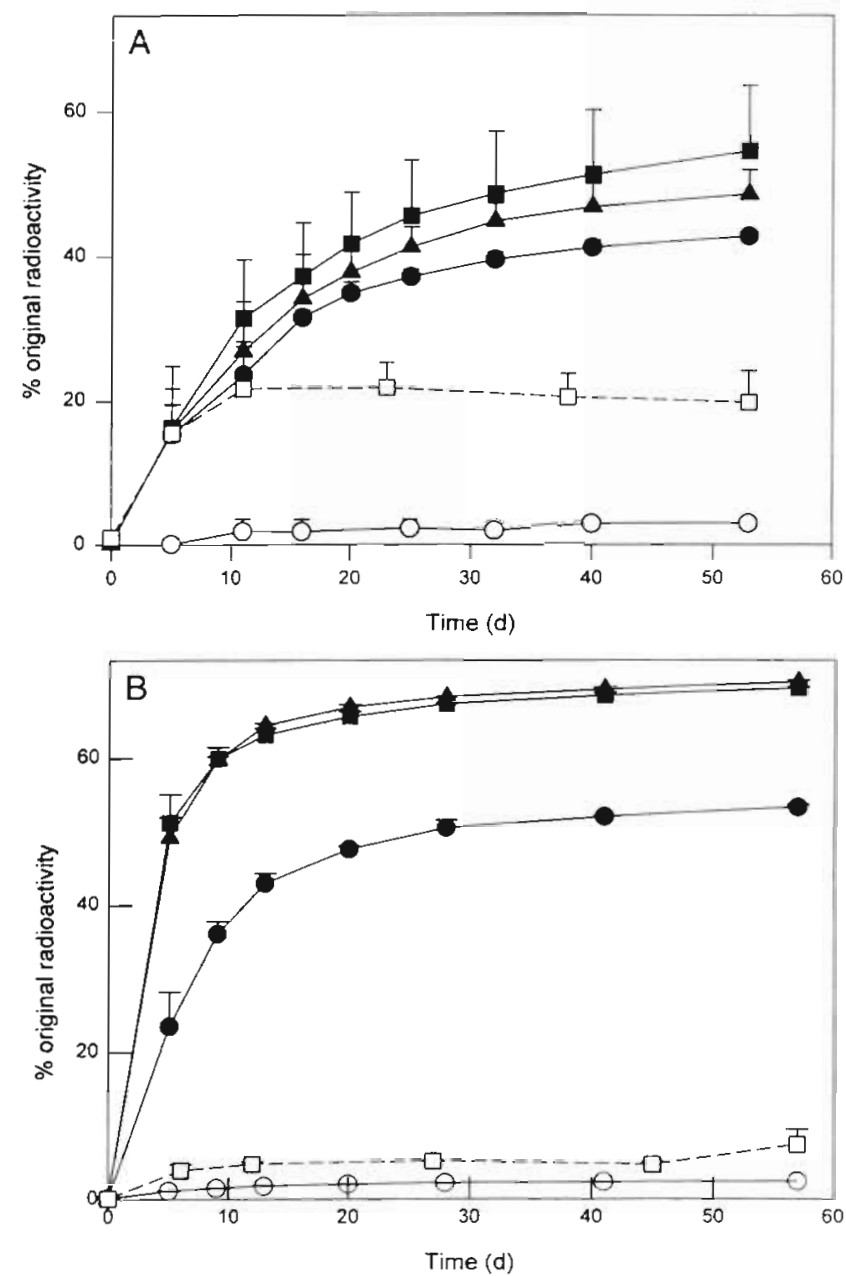

Fig. 5. (A) Time course of ${ }^{14} \mathrm{CO}_{2}$ production from $\mathrm{n}-\left[1-{ }^{14} \mathrm{C}\right]$ hexa-

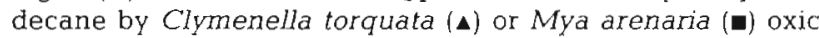
burrow wall sediment slurries, oxic non-burrow sediment $(\bullet)$, anoxic non-burrow sediment (a) or autoclaved controls (0). (B) Time course of ${ }^{14} \mathrm{CO}_{2}$ production from [UL- ${ }^{14} \mathrm{C}$ ]benzene; symbols as for $(A)$. All data are means of triplicates $\pm 1 \mathrm{SE}$. Error bars not shown are < symbol size torquata burrow sediment, although the differences were not statistically significant (Fig. $5 \mathrm{~A}$ ). ${ }^{14} \mathrm{CO}_{2}$ production was greater for burrow than non-burrow sediment and for sediments incubated anaerobically with nitrate as the terminal electron acceptor. In the latter case, $<20 \%$ of the added ${ }^{14} \mathrm{C}$ was recovered as ${ }^{14} \mathrm{CO}_{2}$. Maximum ${ }^{14} \mathrm{CO}_{2}$ accumulation reached approximately $50 \%$ of the added radiotracer during oxic incubations. Activity for killed controls was minimal (1 to $2 \%$ ).

A similar pattern was observed for aerobic ${ }^{14} \mathrm{C}$-benzene degradation: burrow sediments showed significantly higher ${ }^{14} \mathrm{CO}_{2}$ accumulation than did non-burrow sediment (Fig. 5B). Degradation patterns for Mya arenaria and Clymenella torquata sediments were almost identical, with about $66 \%$ of the added radiotracer recovered as ${ }^{14} \mathrm{CO}_{2}$. Only $50 \%$ of the added benzene was mineralized by non-burrow sediment. In contrast to results for ${ }^{14} \mathrm{C}$-hexadecane, anaerobic ${ }^{14} \mathrm{C}$-benzene mineralization was very limited $(<4 \%)$ with nitrate as the final electron acceptor. Results for other electron acceptors were similar (not shown).

\section{PAH degradation}

Naphthalene degradation proceeded rapidiy without a lag in all oxic burrow and non-burrow sediments (Fig. 6A). For burrow sediments, complete loss of naphthalene occurred within $5 d$, with an average loss rate of about $17 \% \mathrm{~d}^{-1}$. Degradation in non-burrow sediments occurred somewhat more slowly, but naphthalene was completely lost within $11 \mathrm{~d}$. Much slower naphthalene losses, about $3 \% \mathrm{~d}^{-1}$, were observed for autoclaved control sediments, primarily as a result of the high volatility of naphthalene.

Oxic degradation of 1,4-DMN was similar among all sediment types assayed except for the autoclaved control (Fig. 6C). A gradual but steady decrease in 1, 4-DMN was observed. As in the naphthalene treatments, degradation occurred without any apparent lag period. The loss rate was about $5 \% \mathrm{~d}^{-1}$ for burrow sediments, and slightly lower $\left(3 \% \mathrm{~d}^{-1}\right)$ for non-burrow sediments. At the end of $19 \mathrm{~d}$, about 90 and $95 \%$ of the added 1,4-DMN were lost from Clymenella torquata and Mya arenaria sediments, respectively.

Oxic Clymenella torquata burrow sediments and non-burrow surface sediments rapidly degraded DBT after initial lag periods of about 12 and $7 \mathrm{~d}$, respectively (Fig. 6D). The average loss rate was about $12 \% \mathrm{~d}^{-1}$ for both sediment types. Little degradation was observed in Mya arenaria and bulk sediments compared to the control. GC-MS analysis revealed a DBT metabolite, DBT sulfoxide in organic extracts from $C$. torquata and surface sediment samples but not extracts of other sediments (data not shown). In con- 

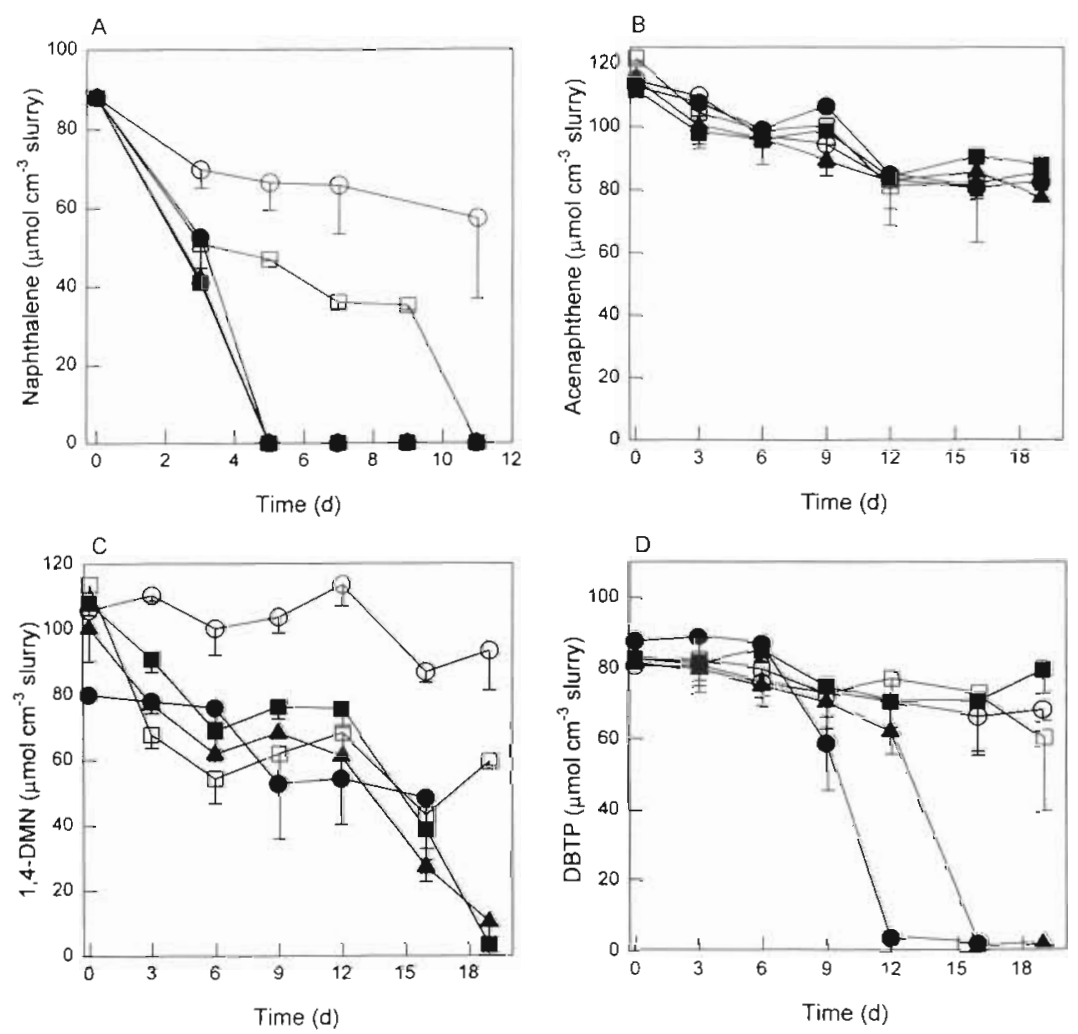

Fig. 6. (A) Time course of (A) naphthalene, (B) acenaphthene, (C) 1, 4-dimethylnaphthalene $(1,4$-DMN) and (D) dibenzothiophene (DBTP) in slurries of oxic non-burrow surface sediments $(\bullet)$, anoxic surface sediments $(\square)$, autoclaved controls (O), or oxic burrow wall sediments from Clymenella torquata (\$) or Mya arenaria (匹). All data are means of triplicates $\pm 1 \mathrm{SE}$. Error bars not shown are $<$ symbol size

trast to DBT and the other PAH, neither acenaphthene (Fig. 6B) nor benz[a]anthracene (data not shown) were degraded relative to sterile controls during the time course of the assays (20 d).

Phenanthrene degradation occurred rapidily after a lag of typically 3 to $7 \mathrm{~d}$ (Figs. 7 \& 8) in Nereis virens burrow sediment slurries incubated under oxic conditions. Complete degradation of $5 \mu \mathrm{g}$ phenanthrene $\mathrm{cm}^{-3}$ slurry was observed within about $48 \mathrm{~h}$ after the initial lag. Phenanthrene degradation did not differ from sterile controls for slurries initially incubated under oxic conditions and subsequently switched to anoxic conditions (Fig. 7). Phenanthrene losses in these controls as in others appeared to arise as a result of changes in adsorption and extraction efficiencies over time.

Phenanthrene was also degraded in slurries incubated under alternating oxic and anoxic conditions ( $24 \mathrm{~h}$ cycle) after an initial $9 \mathrm{~d}$ lag that was equivalent to the lag for slurries incubated under continuously oxic conditions (Fig. 8). However, degradation was markedly slower under the alternat-

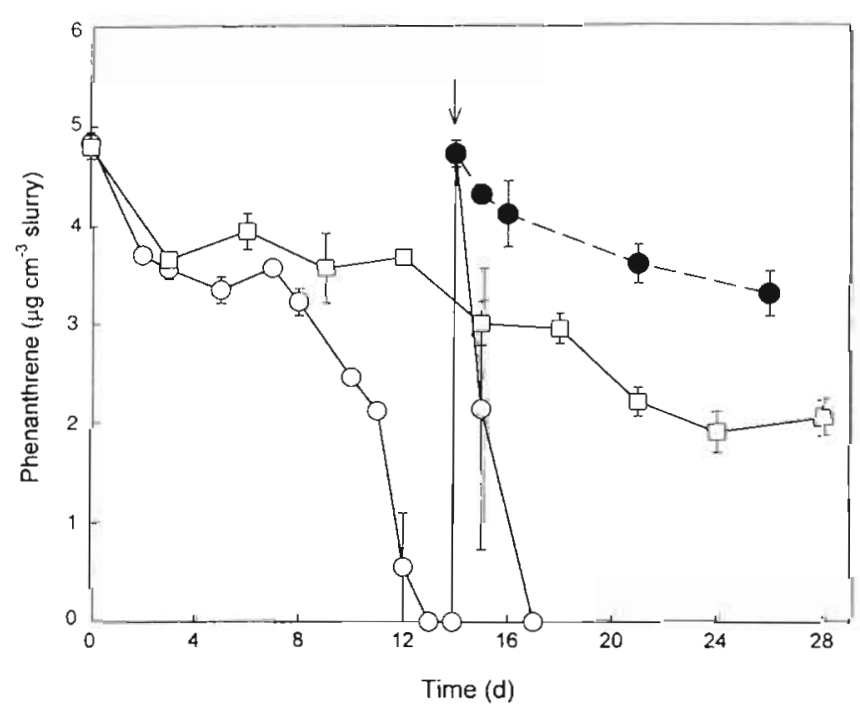

Fig. 7. Time course of phenanthrene in slurries of Nereis virens burrow wall sediment incubated continuously under oxic (O) or anoxic () conditions and after switching from oxic to anoxic conditions ( $\bullet$ ). Arrow indicates addition of phenanthrene $\left(5 \mu \mathrm{g} \mathrm{cm}^{-3}\right.$ slurry). All data are means of triplicates $\pm 1 \mathrm{SE}$

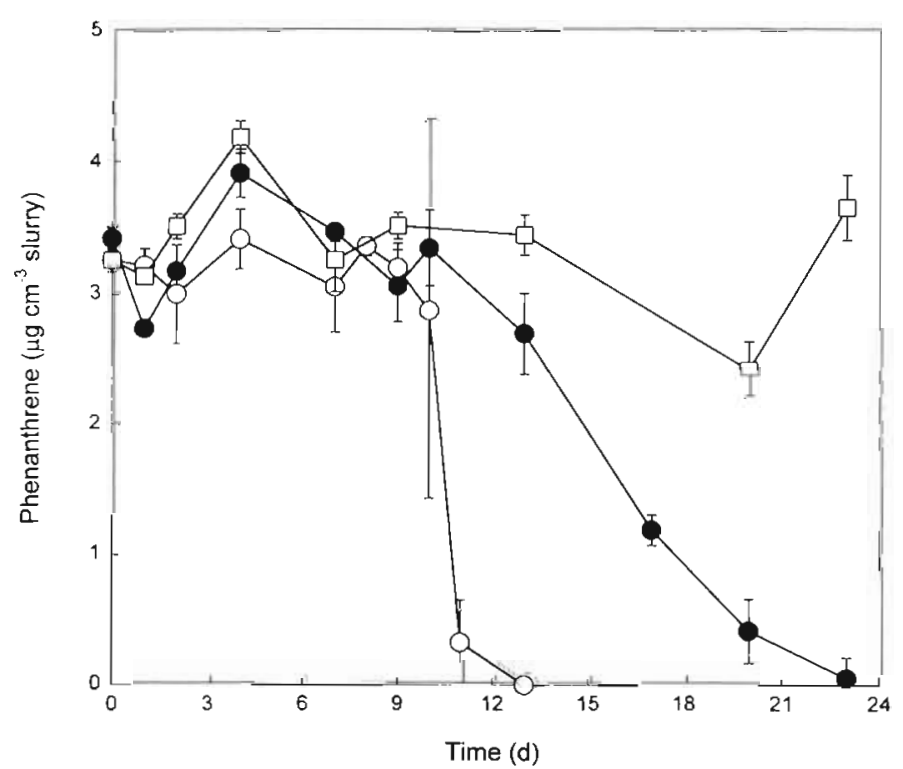

Fig. 8. Time course of phenanthrene in slurries of Nereis virens burrow wall sediment incubated continuously under oxic (o) or anoxic (ㅁ) conditions or with alternating oxic and anoxic conditions on a $24 \mathrm{~h}$ cycle $(\bullet)$. All data are means of triplicates $\pm 1 \mathrm{SE}$ 


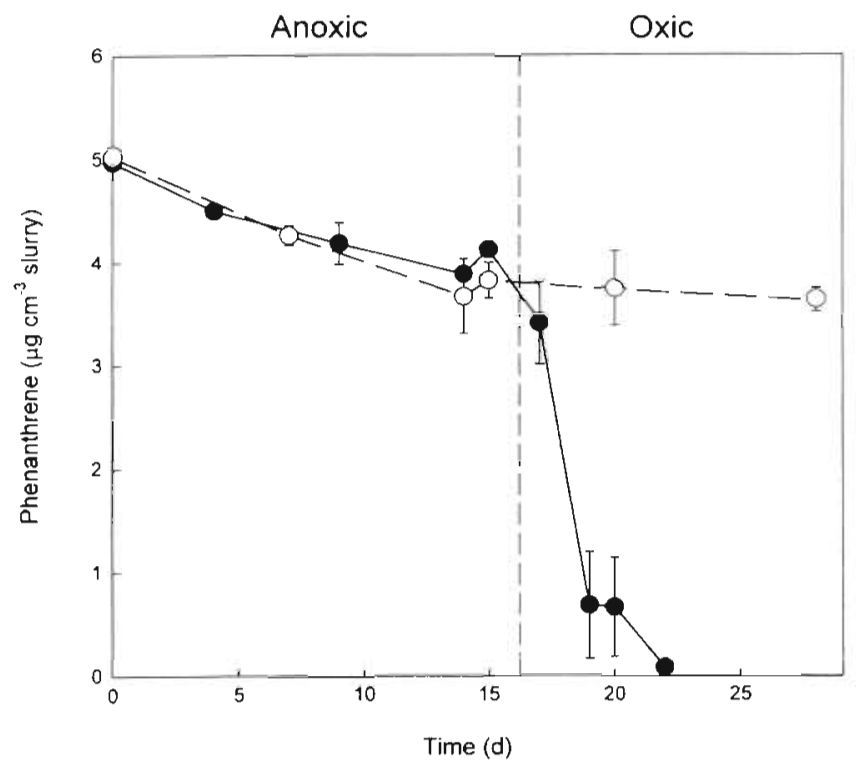

Fig. 9. Time course of phenanthrene in slurries of Nereis virens burrow wall sediment incubated initially under anoxic conditions with added nitrate $(\bullet)$; dashed line indicates switch to oxic conditions; (O) autoclaved control. All data are means of triplicates $\pm 1 \mathrm{SE}$

ing regime (approximately 13 vs $3 \mathrm{~d}$ for complete degradation). In contrast, pre-incubation under anoxic conditions for $2 \mathrm{wk}$ did not result in an extended lag period for or reduce rates of phenanthrene degradation subsequent to oxygen introduction (Fig. 9). Addition of nitrate or other terminal electron acceptors (manganese, iron) did not alter the outcome of assays with an anoxic pre-incubation (data not shown). Apparent losses in the presence of nitrate were comparable to those of sterile controls in similar assays.

\section{DISCUSSION}

Since benthic microbial communities and their processes are governed in a large part by local oxygen regimes (Fenchel et al, 1998), burrows and burrow ventilation can have a substantial impact on the distribution and activity of various bacterial functional groups. Ammonia oxidizers, which depend strictly on molecular oxygen, are thus active along burrow walls in addition to oxic surficial sediments (Kristensen 1984). Likewise, sulfidogens are active in intermittently anoxic burrow sediments (Reichardt 1988) as well as in anoxic subsurface sediments and anoxic microzones in oxic sediments. The distribution and rates of these and other processes vary among burrow types, which is not surprising since burrowing and ventilating behavior vary considerably among macrofauna, even for congeneric taxa (Kristensen 1981, 1983a,b).
However, in this study, marked variations in inner burrow wall sulfate reduction rates (Table 1, Fig. 1A) do not correlate obviously with burrow ventilation or behavioral characteristics (e.g motility, feeding mode), since rates for Mya arenaria are typically lower than those for the 2 polychaetes. Due to its relatively sedentary nature and ventilation through siphons, $M$. arenaria should enhance anoxia locally and stimulate sulfate reduction, although some oxygen diffusion through siphons may occur. The patterns for $M$. arenaria suggest that parameters other than ventilation determine activity. These unspecified parameters may account for the fact that sulfate reduction rates and potential denitrification rates vary roughly inversely among Clymenella torquata, $M$. arenaria, and Nereis virens (see Table 1, Fig. 10), while there are no apparent relationships between potential ammonia oxidation and sulfate reduction.

Sulfate reduction rates observed along burrow transects (Fig. 1A) are consistent with trends observed for inner burrow wall sediments alone. Over the entire 2 to $3 \mathrm{~cm}$ transect, rates are highest for Nereis virens, with intermediate values for Mya arenaria, and the lowest average values for Clymenella torquata. A decrease in the inhibitory impact of intermittent oxygenation may account for the increase in sulfate reduction with distance. However, a variety of other factors may also be involved, since Hansen et al. (1996) observed both increases and decreases in sulfate reduction in transects from $M$. arenaria burrow walls.

Potential denitrification rates vary markedly among the burrow types as well (Table 1, Fig. 2), but in this case it is possible to suggest relationships between macrofaunal characteristics and microbial activity. The

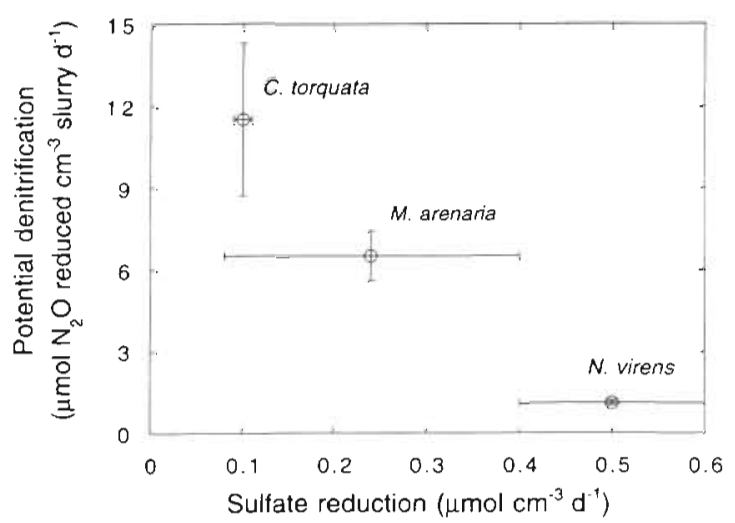

Fig. 10. Maximum potential denitrification and sulfate reduction rates for burrow wall sediments of Clymenella torquata, Mya arenana and Nereis virens. Denitrification rates were assayed using slurries; sulfate recluction rates were measured using undiluted sediment incubated in syringes (see text for details) 
highest potential denitrification rates occur for sediments from Clymenella torquata and Mya arenaria. The formation of a semi-permanent, parchment-like burrow structure by $C$. torquata may limit the extent of solute exchange between burrow water and porewater, thereby increasing the relative extent of anoxia around the burrow. The siphons of $M$. arenaria may have a similar effect. Differences in the extent of anoxia among macrofaunal taxa could be manifest in denitrifier population sizes or in the expression of denitrifying enzymes, either of which would be reflected in estimates of maximum potential activity. On the other hand, potential denitrification and ammonia oxidation are not correlated (Fig. 10), even though the latter is likely the predominant source of nitrate for the former (Kristensen 1988, Blackburn et al. 1994).

Potential ammonia oxidation is highest for Nereis virens and least for Mya arenaria, with intermediate values for the remaining taxa. Giray \& King (1997) and Kristensen (1988) previously reported a similar trend. Differences among taxa may reflect differences in burrow wall physical characteristics (e.g. organic content, mucus) as suggested by Kristensen (1988), as well as differences in the nature and extent of burrow irrigation. The latter may account for the low ammonia oxidation potential of $M$. arenaria in particular since irrigation through its siphons precludes direct contact between overlying water and burrow sediment. In contrast, surface water is in direct contact with burrow sediment during irrigation by polychaetes and enteropneusts, though the timing and volume of flow may vary considerably among taxa.

Although the specific mechanisms that account for the preceding biogeochemical patterns are uncertain, it is likely that they affect a wide range of microbial activities, including PAH degradation. While some recent evidence indicates that several aromatics can be degraded anaerobically (Grbic-Galic \& Vogel 1987. Lovley et al. 1989, Edwards et al. 1992, Coates et al. 1997), data from this study suggest that oxic degradation dominates in largely uncontaminated sediments. For example, aerobic benzene degradation occurs rapidly in burrow and non-burrow sediments, but is minimal under anoxic conditions. Likewise, even though hexadecane appears more labile than benzene under anoxic conditions, oxic degradation still dominates total activity (Fig. 5). In the case of phenanthrene, no degradation occurs under anoxic conditions, irrespective of the available terminal electron acceptor (Figs. 7 to 9), while aerobic degradation is rapid after a short lag phase. The observed lag phase most likely represents the time required for induction and synthesis of dioxygenases suitable for PAH degradation.

In contrast to oxic surface sediments, oxygen is available in burrow sediments only intermittently, since burrow ventilation is a periodic process (Scott 1975 , Kristensen 1981, 1983a,b). The nature of ventilation is not well described, but appears to vary substantially among the macrobenthos. Nereis virens typically ventilates its burrows for short intervals (about $5 \mathrm{~min}$ ) interspersed among longer resting periods (about $30 \mathrm{~min})$; in addition, much longer periods of quiescence (hours) occur with no ventilation (Scott 1975). During the latter, rapid oxygen uptake by burrow sediments and animal tissues can lead to cessation of aerobic microbial metabolism, initiation of anaerobic metabolism, excretion of organic acid metabolites by the burrow host and decreases in burrow water $\mathrm{pH}$ (Scott 1975). Experimental evidence suggests that such periodic oscillations can stimulate bulk organic matter degradation (Aller 1994).

Data presented here indicate that periodic variations in oxygen levels do not preclude aerobic phenanthrene degradation by Nereis virens sediment slurries when oxygen is available. After initiation under oxic conditions, phenanthrene degradation ceases upon oxygen removal, but resumes without lag after reintroduction of oxygen (Figs. $7 \& 8$ ). Further, complete loss of exogenous phenanthrene occurs under alternating oxic-anoxic conditions, albeit at a slower rate than under continuously oxic conditions. Repeated oxicanoxic shifts appear to have little cumulative effect since degradation rates remain approximately constant during oxic phases (Fig. 8). Thus, short-term anoxia $(24 \mathrm{~h})$ has little deleterious effect on phenanthrene degraders. Likewise, long-term anoxia has little deleterious effect. Lag times for and rates of phenanthrene degradation after introduction of oxygen are comparable for sediments incubated initially for $2 \mathrm{wk}$ under anaerobic conditions or incubated continuously under oxic conditions (Fig. 9).

In this context, phenanthrene degraders share traits with other oxygen-dependent functional groups. Ammonia oxidizers appear most abundant in periodically anoxic burrow wall sediments based on maximum potential oxidation rates (e.g. Fig. 4 and Kristensen 1988), yet cannot oxidize ammonia anaerobically. Methane-oxidizing bacteria also depend on molecular oxygen, but tolerate extended periods of anoxia well (Roslev \& King 1994). Thus, survival under anaerobic conditions may be a relatively general phenomenon among aerobic bacteria that promotes their persistence and activity in intermittently oxic environments. Although the ability to respire anaerobically (e.g. with nitrate) may account for anoxia tolerance of some bacterial groups, it is not clear to what extent this is important for PAH degraders.

The biogeochemical patterns and trends for PAH degradation evident in this study indicate that burrow sediments cannot be considered a simple extension of 
the sediment surface. Others looking at different taxa and processes have reached similar conclusions (Kristensen et al. 1985, Aller 1988, 1994). While naphthalene and 1, 4-DMN degradation (Fig, 6A,B) occur similarly in each of the various burrow and non-burrow sediments, DBT degradation is sediment-specific, occurring only for Clymenella torquata and surface sediments (Fig. 6C). This pattern differs notably from those for sulfate reduction, denitrification and ammonia oxidation, variations in which may be attributed to differences in population sizes of otherwise similar microbial communities. In contrast, variability in $\mathrm{PAH}$ degradation suggests that different burrow sediments may harbor characteristic phylogenetically and functionally diverse ensembles of PAH degraders. The specific nature of these ensembles might reflect variations in physical regimes resulting from diverse ventilation patterns. Altematively, different macrofaunal taxa may excrete metabolites that select for certain populations with specific capacities. In support of these notions, 3 morphologically and physiologically distinct isolates have been obtained from burrows of Nereis virens, Mya arenaria and C. torquata (Chung \& King 1998).

Recently, Berardesco et al. (1998) documented very diverse communities of phenanthrene-degrading bacteria isolated from surficial sediments of Boston Harbor. Spatial (but not temporal) variations in the diversity of this community at the cm scale appear minimal. While small-scale variations in the diversity of PAH degraders in Lowes Cove surface sediments might also be limited, results reported here indicate that significant sub-surface variation may occur as a consequence of macrofaunal diversity. The extent of such variation may ultimately contribute to differential fates for the various components of PAH found in situ.

Benthic macrofauna can also affect the fate of PAH through other mechanisms. Sediment reworking by deposit-feeding and burrowing re-distributes PAH to the water column and oxic sediment surfaces, thereby enhancing the potential for aerobic degradation (e.g. Koerting-Walker \& Buck 1989, McElroy et al. 1990). In addition, macrofauna can assimilate and metabolize some PAH directly (Karlckhoff \& Morris 1985, McElroy 1990, Forbes et al. 1996). Although the relative significance of these processes and burrow wall degradation remain uncertain, it seems evident that manipulation of benthic macrofaunal populations and their associated microbiota represents a viable approach for in situ bioremediation of contaminated marine sediments.

Acknowledgements. We thank Kathleen Hardy in particular and also Dr C. Giray for technical support, and acknowledge funding from the Office of Naval Research (N00014-96-10592).

\section{LITERATURE CITED}

Aller RC (1982) The effect of macrobenthos on chemical properties of marine sediment and overlaying water. In: McCall PL, Tevesz MJS (eds) Animal-sediment relations: the biogenic alterations of sediments. Plenum Publishing Company, New York, p 53-102

Aller RC (1988) Benthic fauna and biogeochemical processes in marine sediments: the role of burrow structures. In: Blackburn TH, Sorensen J (eds) Nitrogen cycling in coastal marine environments. John Wiley \& Sons, Chichester, p 301-338

Aller RC (1994) Bioturbation and remineralization of sedimentary organic matter: effects of redox oscillation. Chem Geol 114:331-345

Anderson FE, Black L, Watling LE, Mook W, Mayer LM (1981) A temporal and spatial study of mudflat erosion and deposition. J Sediment Petrol 51:729-736

Arcangeli JP, Arvin E (1995) Cometabolic transformation of o-xylene in a biofilm system under nitrate-reducing conditions. Biodegradation 6:19-27

Banta GT, Holmer M, Jensen MH, Kristensen E (1999) Effects of two polychaete worms, Nereis diversicolor and Arenicola marina, on aerobic and anaerobic decomposition in a sandy marine sediment. Aquat Microb Ecol 19:189-204

Baver JE, Capone DG (1985) Degradation and mineralization of the polycyclic aromatic hydrocarbons anthracene and naphthalene in intertidal marine sediments. Appl Environ Microbiol 50:81-90

Bauer JE, Capone DG (1988) Effects of co-occurring aromatic hydrocarbons on degradation of individual polycyclic aromatic hydrocarbons in marine sediment slurries. Appl Environ Microbiol 54:1849-1865

Bedessem ME, Swoboda-Colberg NG, Colberg PJS (1997) Naphthalene mineralization coupled to sulfate reduction aquifer-derived enrichments. FEMS Microbiol Lett 152: 213-218

Beller HR, Spormann AM, Sjarma PK, Cole JR, Reinhard M (1996) Isolation and characterization of a novel toluenedegrading, sulfate-reducing bacterium. Appl Environ Microbiol 62:1188-1196

Belser LW, Mays EL (1980) Specific inhibition of nitrite oxidation by chlorate and its use in assessing nitrification in soils and sediments. Appl Environ Microbiol 39:505-510

Berardesco G, Dyhrman S, Gallagher E, Shiaris MP (1998) Spatial and temperal variation of phenanthrene-degrading bacteria in intertidal sediments. Appl Environ Microbiol 64:2560-2565

Blackburn TH, Blackburn ND (1993) Rates of microbial processes in sediments. Philos Trans R Soc Lond 344(A):49-58

Blackburn TH, Blackburn ND, Jensen K, Risgaard-Petersen N (1994) Simulation model of the coupling between nitrification and denitrification in a freshwater sediment. Appl Environ Microbiol 60:3089-3095

Boldrin B, Tiehm A, Fritzsche C (1993) Degradation of phenanthrene, fluoranthene, and pyrene by a Mycobacterium sp. Appl Environ Microbiol 59:1927-1930

Bossert ID, Young LY (1986) Anaerobic oxidation of p-cresol by a denitrifying bacterium. Appl Environ Microbiol 52: $1117-1122$

Bussman I, Reichardt W (1991) Sulfate-reducing bacteria in temporarily oxic sediments with bivalves. Mar Ecol Prog Ser 78:97-102

Chung WK, King GM (1998) Controls of PAH degradation in burrow wall sediments of marine macrofauna. Abstract 98th Annual Meeting Amer Soc Microbiol 437, Atlanta, GA 
Coates JD, Woodward J, Allen J, Philp P, Lovley DR (1997) Anaerobic degradation of polycyclic aromatic hydrocarbons and alkanes in petroleum-contaminated marine harbor sediments. Appl Environ Microbiol 63:3589-3593

Delaune RD, Patrick WH, Casselman ME (1981) Effect of sediment $\mathrm{pH}$ and redox conditions on degradation of benz[a]pyrene. Mar Pollut Bull 12:251-253

Edwards EA, Wills LE, Reinhard M, Grbic-Galic D (1992) Anaerobic degradation of toluene and xylene by aquifer microorganisms under sulfate reducing conditions. Appl Environ Microbiol 58:794-800

Evans PJ, Mang DT, Young LY (1991) Degradation of toluene and $m$-xylene and transformation of o-xylene by denitrifying enrichment cultures. Appl Environ Microbiol 57:450-454

Fenchel T, King GM, Blackburn TH (1998) Bacterial biogeochemistry: the ecophysiology of mineral cycling. Academic Press, New York

Forbes VE, Forbes TL, Holmer M (1996) Inducible metabolism of fluoranthene by the opportunistic polychaete Capitella sp. 1. Mar Ecol Prog Ser 132:63-70

Fritzsche C (1994) Degradation of pyrene at low oxygen concentrations by a Mycobacterium sp. Appl Environ Microbiol 60:1687-1689

Gilbert F, Bonnin P, Stora G (1995) Effect of bioturbation on denitrification in a marine sediment from the west Mediterranean iittoral. Hydrobiologia 304:49-58

Giray C, King GM (1997) Effect of naturally occurring bromophenols on sulfate reduction and ammonia oxidation in sediments from a Maine mudflat. Aquat Microb Ecol 13: 295-301

Grbic-Galic D, Vogel TM (1987) Transformation of toluene and benzene by mixed methanogenic cultures. Appl Environ Microbiol 53:254-260

Hansen K, King GM, Kristensen E (1996) Impact of the softshell clam Mya arenaria on sulfate reduction in an intertidal sediment. Aquat Microb Ecol 10:181-194

Jenkins BM, Jones AD, Turn SQ, Williams RB (1996) Emission factors for polycyclic aromatic hydrocarbons from biomass burning. Environ Sci Technol 30:2462-2469

Kanaly R, Bartha R, Fogel S, Findlay M (1997) Biodegradation of [14C]benz[a]pyrene added in crude oil to uncontaminated soil. Appl Environ Microbiol 63:4511-4515

Karlckhoff SW, Morris KR (1985) Impact of tubificid oligochaetes on pollutant transport in bottom sediments. Environ Sci Technol 19:51-56

King GM, KJug MJ, Lovley DR (1983) Metábolism of acetate, methanol, and methylated amines in intertidal sediments of Lowes Cove, Maine. Appl Environ Microbiol 45: 1848-1853

Koerting-Walker C, Buck JD (1989) The effect of bacteria and bioturbation by Clymenella torquata on oil removal from sediment. Water Air Soil Pollut 43:413-424

Kristensen E (1981) Direct measurement of ventilation and oxygen uptake in three species of tubicolous polychaetes (Nereis spp.). J Comp Physiol 145(B):45-50

Kristensen E (1983a) Ventilation and oxygen uptake by three species of Nereis (Annelida: Polychaeta). I. Effects of hypoxia. Mar Ecol Prog Ser 12:289-297

Kristensen E (1983b) Ventilation and oxygen uptake by three species of Nereis (Annelida: Polychaeta). II. Effects of temperature and salinity changes. Mar Ecol Prog Ser 12: 299-306

Kristensen E (1984) Effect of natural concentrations on nutrient exchange between a polychaete burrow in estuarine sediment and the overlaying water. J Exp Mar Biol Ecol 75:171-190

Kristensen E (1988) Benthic fauna and biogeochemical processes in marine sediments: microbial activities and fluxes. In: Blackburn TH, Sorensen J (eds) Nitrogen cycling in coastal marine environments. John Wiley \& Sons, Chichester, p 275-299

Kristensen E, Jensen MH, Andersen TK (1985) The impact of polychaete (Nereis virens) burrows on nitrification and nitrate reduction in estuarine sediments. J Exp Mar Biol Ecol 85:75-91

Kristensen E, Jensen MH, Aller RC (1991) Direct measurement of dissolved inorganic nitrogen exchange and denitrification in individual polychaete (Nereis virens) burrows. J Mar Res 49:355-377

Lovley DR, Baedecker MJ, Longergan DJ, Cozzarelli LM Phillips JP, Siegel DI (1989) Oxidation of aromatic contaminants coupled to microbial iron reduction. Nature 339: 297-300

McElroy AE (1990) Polycyclic aromatic hydrocarbon metabolism in the polychaete, Nereis virens. Aquat Toxicol 18: $35-50$

McElroy AE, Farrington JW, Teal JM (1990) Influence of mode of exposure and the presence of a tubiculous polychaete on the fate of benz[a]anthracene in the benthos. Environ Sci Technol 24:1648-1655

Menzie CA, Potocki BB, Santodonato J (1992) Exposure to carcinogenic PAHs in the environment. Environ Sci Technol 26:1278-1284

Mihelic JR, Luthy RG (1988) Degradation of polycyclic aromatic hydrocarbon compounds under various redox conditions in soil-water systems. Appl Environ Microbiol 54: $1182-1187$

Pelegri SP, Blackburn TH (1996) Effect of bioturbation by Nereis sp., Mya arenaria and Cerastoderma sp. on nitrification and denitrification in estuarine sediments. Ophelia 42:289-299

Rabus R, Nordhaus R, Ludwig W, Widdle F (1993) Complete oxidation of toluene under strictly anoxic conditions by a new sulfate-reducing bacterium. Appl Environ Microbiol 59:1444-1451

Reichardt W (1988) Impact of bioturbation by Arenicola marina on microbiological parameters in intertidal sediments. Mar Ecol Prog Ser 44:149-158

Rice DL (1986) Early diagenesis in bioadvective sediments relationships between the diagenesis of beryllium- 7 , sediment reworking rates, and the abundance of conveyorbelt deposit-feeders. J Mar Res 44:149-184

Roslev P, King GM (1994) Survival and recovery of methanotrophic bacteria under oxic and anoxic conditions. Appl Environ Microbiol 60:2602-2608

Sayama M. Kurihara Y (1983) Relationship between burrowing activity and the polychaetous annelid Neanthes japonica (Izuka) and nitrification-denitrification processes in the sediments. J Exp Mar Biol Ecol 72:233-241

Scott DM (1975) Respiration and ventilation of the polychaete Nereis virens (Sars). University of Maine, Orono

Sharak-Genthner BR, Townsend GT, Lantz SE, Mueller JG (1997) Persistence of polycyclic aromatic hydrocarbon components of creosote under anaerobic enrichment conditions. Arch Environ Contam Toxicol 32:99-105

Sverdrup HU, Johnson MW, Fleming RH (1942) The oceans: their physics, chemistry, and general biology. PrenticeHall, Inc, New York, p 165-227 